\title{
Prawno-administracyjne aspekty ochrony środowiska
}

Ochrona środowiska to dziedzina prawa o charakterze interdyscyplinarnym, w której regułą jest posługiwanie się pojęciami właściwymi dla nauk prawniczych, przyrodniczych, technicznych czy chemicznych. Dlatego w praktyce mogą mieć one różne znaczenie pojęciowe w zależności od kontekstu, w jakim zostały użyte. Pojęcie, które zwraca uwagę na prawa i obowiązki obywateli, organów administracji publicznej czy też organizacji ekologicznych, to prawno-administracyjne aspekty ochrony środowiska. Jeżeli chodzi o legitymację czynną, podstawowe znaczenie ma tu art. 4 ustawy prawo ochrony środowiska ${ }^{1}$, gdzie zostały określone formy, w jakie może być ujęte korzystanie ze środowiska oraz komu przysługują uprawnienia w tym zakresie. W tym samym artykule zostało wprowadzone tzw. powszechne korzystanie ze środowiska.

Wprowadzenie rozwiązań ustawowych znalazło oparcie w normach konstytucyjnych, które zapewniają bezpieczeństwo ekologiczne, ochronę środowiska oraz dbałość o jego stan. Ochrona środowiska w ramach polityki prowadzonej przez państwo, to rozwój społeczno-gospodarczy, w którym działania polityczne, gospodarcze i społeczne są zintegrowane, w celu zagwarantowania współczesnemu i przyszłym pokoleniom możliwości zaspokajania podstawowych potrzeb. Należy uznać, iż art. 5 Konstytucji $\mathrm{RP}^{2}$ wskazuje najbardziej istotne wartości i najbardziej podstawowe cele, $\mathrm{w}$ których realizację winny się włączyć wszelkie organy władzy publicznej, wykorzystując wszystkie ich kompetencje. Zakres przedmiotowy konstytucyjnych norm prawnych stanowi o tym, iż każdy ma prawo do ochrony zdrowia. Władze publiczne prowadzą zatem politykę zapewniającą bezpieczeństwo ekologiczne współczesnemu i przyszłym pokoleniom, gdyż ochrona środowiska jest obowiązkiem władz publicznych. Realizacja tego obowiązku stwarza możliwość dla obywateli powzięcia wiadomości o działaniach podejmowanych przez administrację państwową. Z powszechnym prawem do informacji skorelowany jest obowiązek każdego do dbałości o stan środowiska

\footnotetext{
Dz. U. z 2001r., Nr 62, poz. 627.
}

2 Dz. U. z 1997r., Nr 78, poz. 483. 
i ponoszenia odpowiedzialności za spowodowane przez siebie jego pogorszenie. Warunkiem sine qua non dla prawidłowego realizowania standardów ochrony środowiska jest jasne, proste i precyzyjne sporządzanie aktów prawnych, które mają być przejrzyste i łatwo zrozumiałe przez obywateli oraz podmioty gospodarcze. Zgodnie z orzecznictwem Trybunału Sprawiedliwości zasada bezpieczeństwa prawnego, która jest częścią wspólnotowego porządku prawnego, wymaga, aby prawodawstwo wspólnotowe było jasne i precyzyjne, a jego stosowanie możliwe do przewidzenia przez obywateli. Wymóg ten musi być zachowany szczególnie bezwzględnie w przypadku aktu mogącego mieć skutki finansowe i nakładającego obowiązki na obywateli, tak aby zainteresowani mogli dokładnie poznać zakres obowiązków, które nakłada na nich ten akt ${ }^{3}$. Jak podkreśla się również $\mathrm{w}$ doktrynie, postanowienia zawarte w pierwszym rozdziale Konstytucji zbudowane są z pojęć ogólnych, w ustawie zasadniczej niezdefiniowanych, mających jednak ustaloną treść doktrynalną i z reguły znanych judykaturze ${ }^{4}$.

Przepisy Konstytucji ustanawiają obywatelskie prawo do środowiska, którego treść wyprowadzić można $\mathrm{z}$ art. 5, 68 ust. 4, art. 74 oraz art. 86, natomiast prawo podmiotowe wyrażone $\mathrm{w}$ art. 74 ust. 3 jest gwarancją jego realizacji. Wskazanie zasady zrównoważonego rozwoju, jako ustrojowej zasady konstytucyjnej powoduje obowiązek kierowania się nią przez państwo $\mathrm{w}$ realizacji swoich podstawowych funkcji określonych w art. 5 Konstytucji. Dotyczy to wszelkich organów państwa, a więc organów władzy publicznej. Obejmuje to organy ustawodawcze, wykonawcze i sądownicze w całej ich działalności. Oznacza to chociażby konieczność uwzględnienia zasady zrównoważonego rozwoju w stanowieniu prawa.

Władze państwowe powinny wspierać obywateli w ich działaniach na rzecz ochrony i poprawy stanu środowiska. Bezpieczeństwo ekologiczne, które ma być zapewnione przez władze publiczne to stan środowiska pozwalający na bezpieczne przebywanie $\mathrm{w}$ nim i korzystanie $\mathrm{z}$ niego. Instrumentem zapewnienia tego bezpieczeństwa jest ochrona środowiska, która pełni rolę dyrektywy wykładni, gdy pojawiają się wątpliwości co do zakresu obowiązków, rodzaju obowiązków i sposobu ich realizacji. Jest towarem rola podobna do zasad współżycia społecznego czy społeczno-gospodarczego przeznaczenia w prawie cywilnym. W pierwszej kolejności do uwzględniania standarów ochrony środowiska obowiązany jest ustawodawca $\mathrm{w}$ procesie stanowienia prawa, ale $\mathrm{z}$ drugiej zasadę te powinny mieć na uwadze organy stosujące prawo. Niekiedy bowiem stan faktyczny wymaga rozważenia i wyważenia rozwiązań korzystniejszych stosując zasadę zrównoważonego rozwoju. Koncepcja zrównoważonego rozwoju to kompleksowa odpowiedź na środowiskowe, ekonomiczne i społeczne wyzwania współcze-

\footnotetext{
3 Porozumienie międzyinstytucjonalne w sprawie wspólnych wytycznych dotyczacych jakości prawodawstwa wspólnotowego z dnia 22 grudnia 1998 roku (Dz. U. UE C z dnia 17 marca 1999 r.).

4 Wyrok Trybunału Konstytucyjnego z dnia 13 maja 2009 roku (Kp 2/09).
} 
snego świata, która znacząco rozszerza zakres dyskusji prowadzonej do tej pory w ramach ochrony środowiska 5 .

Zakres przedmiotowy art. 5 Konstytucji stanowi, że zasada zrównoważonego rozwoju odnosi się do wszystkich wskazanych tam funkcji państwa, co implikuje skutek w takiej postaci, że mamy do czynienia z zasadą ustrojową, gdzie dochodzi do:

1) wprowadzenia zasady zrównoważonego rozwoju, jako zasady ustrojowej odnoszącej się do podstawowych zadań państwa,

2) określenie ochrony środowiska, jako jednej z podstawowych funkcji państwa. Władze publiczne są zobowiązane zatem do prowadzenia polityki zapewniającej bezpieczeństwo ekologiczne współczesnemu i przyszłym pokoleniom. Sformułowanie to ma charakter typowy dla określenia polityki ekologicznej państwa, nie rodzi natomiast bezpośrednio jakichkolwiek praw podmiotowych po stronie jednostki. Pojęcie „bezpieczeństwo ekologiczne” należy rozumieć jako uzyskanie takiego stanu środowiska, który pozwala na bezpieczne przebywanie $\mathrm{w}$ tym środowisku i umożliwia korzystanie $\mathrm{z}$ tego środowiska w sposób zapewniający rozwój człowieka. Ochrona środowiska jest jednym z elementów „bezpieczeństwa ekologicznego", ale zadania władz publicznych są szersze - obejmują też działania poprawiające aktualny stan środowiska i programujące jego dalszy rozwój. W ramach zasady zrównoważonego rozwoju mieści się nie tylko ochrona przyrody, ale i troska o rozwój społeczny i cywilizacyjny, związany z koniecznością budowania stosownej infrastruktury.

W ustawie prawo ochrony środowiska nastąpiło dookreślenie pojęcia „ochrona środowiska". Oparcie analizowanej definicji legalnej na zasadzie zrównoważonego rozwoju sprawiło zmianę charakteru podejmowanych działań ochronnych. Należy tak chronić poszczególne elementy środowiska, by mieć na uwadze przede wszystkim ochronę życia i zdrowia ludzi. Oznacza to, że „ochrona środowiska" w obecnym stanie prawnym ma charakter podmiotowy, co jest zgodne z koncepcją ochrony środowiska w świetle art. 74 Konstytucji. Natomiast art. 1 ustawy prawo ochrony środowiska określa zasady ochrony środowiska oraz warunki korzystania z jego zasobów, z uwzględnieniem wymagań zrównoważonego rozwoju. W ramach przyjętych założeń generalnych ustalono zasady ustalania warunków ochrony zasobów środowiska, czy też obowiązki organów administracji. Ustawa definiuje zrównoważony rozwój, jako rozwój społeczno-gospodarczy, w którym następuje proces integrowania działań politycznych, gospodarczych i społecznych, z zachowaniem równowagi przyrodniczej oraz trwałości podstawowych procesów przyrodniczych, w celu zagwarantowania możliwości zaspokajania podstawowych potrzeb poszczególnych społeczności lub obywateli zarówno współczesnego pokolenia, jak i przyszłych pokoleń.

A. PAwŁowski, Rozwój zrównoważony - idea, filozofia praktyka, Lublin 2008, s. 9. 
Jednym z najistotniejszych elementów, które urzeczywistnia zapisy ustawowe jest polityka ekologiczna państwa mająca na celu stworzenie warunków niezbędnych do realizacji ochrony środowiska. Polityka ekologiczna państwa, na podstawie aktualnego stanu środowiska, określa w szczególności: cele ekologiczne, priorytety ekologiczne, poziomy celów długoterminowych, rodzaj i harmonogram działań proekologicznych, środki niezbędne do osiągnięcia celów, w tym mechanizmy prawno-ekonomiczne i środki finansowe.

Konstytucja ustanawia nakaz zapewnienia ochrony środowiska oraz obowiązki zapewnienia bezpieczeństwa ekologicznego, ochrony środowiska i dbałości o jego stan. Rzeczpospolita Polska zapewnia ochronę środowiska, kierując się zasadą zrównoważonego rozwoju. Przepis ten, zamieszczony w pierwszym rozdziale Konstytucji, zawierającym zasady i założenia uznane przez ustawodawcę za szczególnie ważne dla państwa, wskazuje podstawowe cele i zarazem zadania państwa. Niewątpliwie jest to jeden z przepisów zawierających normy programowe, adresowane głównie do Parlamentu, od którego zależą tempo i sposób ich realiza$\mathrm{cji}^{6}$. Realizacja wymienionych $\mathrm{w}$ tym przepisie zadań należy jednak do wszystkich władz publicznych Rzeczypospolitej - zarówno władzy ustawodawczej, jak i wykonawczej, a także do organów sądowniczych i organów samorządu terytorialnego ${ }^{7}$.

Ustrój terytorialny Rzeczypospolitej Polskiej zapewnia decentralizację władzy publicznej, w której sprawowaniu uczestniczy samorząd terytorialny. Decentralizacja oznacza zaś proces stałego poszerzania uprawnień jednostek władzy publicznej niższego stopnia $\mathrm{w}$ drodze przekazywania im zadań, kompetencji oraz niezbędnych środków. W oparciu o przyjęte zasady ustrojowe nastąpiło zatem delegowanie praw i obowiązków na organy samorządu terytorialnego. Organ wykonawczy województwa, powiatu i gminy, w celu realizacji polityki ekologicznej państwa, sporządza odpowiednio wojewódzkie, powiatowe i gminne programy ochrony środowiska. Programy uchwala odpowiednio sejmik województwa, rada powiatu albo rada gminy.

Obiektywnym recenzentem realizacji przez administrację publiczną obowiązków ustawowych, z którymi immanentnie związana jest zasada zrównoważonego rozwoju, jest społeczeństwo obywatelskie. Minister właściwy do spraw środowiska zapewnia możliwość udziału społeczeństwa, na zasadach i w trybie określonych w ustawie z dnia 3 października 2008 roku o udostępnianiu informacji o środowisku i jego ochronie, udziale społeczeństwa w ochronie środowiska oraz o ocenach oddziaływania na środowisko w postępowaniu, którego przedmiotem jest sporządzenie projektu polityki ekologicznej państwa.

6 J. Boć, Konstytucje Rzeczypospolitej oraz komentarz do Konstytucji RP z 1997 roku, Wrocław 1998, s. 23.

7 P. Winczorek, Komentarz do Konstytucji Rzeczypospolitej Polskiej z dnia 2 kwietnia 1997 r., Warszawa 2000, s. 18. 
Ochrona przyrody w rozumieniu ustawy o ochronie przyrody polega na zachowaniu, zrównoważonym użytkowaniu oraz odnawianiu zasobów, tworów i składników przyrody, między innymi: dziko występujących roślin, zwierząt i grzybów, siedlisk przyrodniczych, tworów przyrody żywej i nieożywionej oraz kopalnych szczątków roślin i zwierząt oraz krajobrazu. Wskazanymi przez ustawodawcę celami ochrony przyrody są między innymi: utrzymanie procesów ekologicznych i stabilności ekosystemów, zachowanie różnorodności biologicznej oraz dziedzictwa geologicznego i paleontologicznego, zapewnienie ciągłości istnienia gatunków roślin i zwierząt wraz z ich siedliskami, ochrona walorów krajobrazowych, a także kształtowanie właściwych postaw człowieka wobec przyrody przez edukację, informowanie i promocję w dziedzinie ochrony przyrody. Powyższe cele realizowane są między innymi przez uwzględnianie wymagań ochrony przyrody w polityce ekologicznej państwa oraz w wojewódzkich, powiatowych i gminnych programach ochrony środowiska, w strategiach rozwoju i planach zagospodarowania przestrzennego województw, w strategiach rozwoju oraz studiach uwarunkowań i kierunków zagospodarowania przestrzennego gmin, w miejscowych planach zagospodarowania przestrzennego, a także przez obejmowanie poszczególnych zasobów, tworów i składników formami ochrony przyrody, opracowywanie i realizację ustaleń planów ochrony dla obszarów podlegających ochronie prawnej oraz prowadzenie badań naukowych i działalności edukacyjnej, informacyjnej i promocyjnej w dziedzinie ochrony przyrody. Reasumując, ochrona przyrody stanowi element ochrony środowiska, a obowiązek dbałości o przyrodę, jako dziedzictwo i bogactwo narodowe, ciąży na organach administracji publicznej, osobach prawnych, oraz osobach fizycznych, przy czym organy administracji obowiązane są do zapewnienia prawnych, organizacyjnych i finansowych warunków ochrony przyrody.

Kolejnym zagadnieniem, który wiąże się z prawno-administracyjnymi aspektami ochrony środowiska jest zasada dostępu do informacji o stanie środowiska. Niewątpliwie najważniejszą rolę odgrywa Konstytucja RP, która w art. 61. ust. 1 gwarantuje obywatelom prawo do uzyskania informacji o działalności organów władzy publicznej i osób pełniących funkcje publiczne, $\mathrm{z}$ uwzględnieniem działalności organów samorządu gospodarczego i zawodowego, a także innych osób oraz jednostek organizacyjnych w zakresie, w jakim wykonują one zadania władzy publicznej i gospodarują mieniem komunalnym lub majątkiem Skarbu Państwa. Jeżeli chodzi o informacje o stanie środowiska, to bardziej szczegółowe rozwiązania wprowadza ustawa zasadnicza $\mathrm{w}$ art. 74 . ust. 3, który gwarantuje każdemu prawo do informacji o stanie i ochronie środowiska. Unormowania konstytucyjne wprowadzają tylko pewne generalne zasady w zakresie prawa do informacji, które wymagają doprecyzowania w innych aktach prawnych. W przypadku zagadnień związanych z ochroną środowiska taki charakter mają posta- 
nowienia ustawy z dnia 6 września 2001 roku o dostępie do informacji publicznej ${ }^{8}$. Oczywiście w celu zapewnienia ochrony właściwego i szybkiego dostępu do informacji niezbędne jest wprowadzenie instrumentów dyscyplinujących organy administracji do szybkiego i sprawnego działania. Dlatego też ustawodawca $\mathrm{w}$ art. 21 ustawy prawo ochrony środowiska określił maksymalne terminy, w jakich powinny być załatwiane sprawy związane $\mathrm{z}$ dostępem do informacji o środowisku. Jednocześnie interpretując kwestie terminów należy pamiętać o postanowieniach art. 35-38 kodeksu postępowania administracyjnego określających terminy załatwienia spraw administracyjnych.

$\mathrm{Z}$ uzyskiwaniem informacji dotyczących środowiska oraz prowadzeniem publicznych wykazów informacji o środowisku oraz udostępnianiem informacji, które mogą podlegać udostępnieniu, są związane określone koszty. Wprowadzenie odpłatności za ich uzyskanie mogłoby w praktyce czynić iluzją zasadę dostępu do informacji o stanie i ochronie środowiska. Dlatego też, próbując zrównoważyć interes publiczny $\mathrm{z}$ interesem podmiotów zainteresowanych uzyskaniem informacji, zdecydowano w art. 24 ust. 1 ustawy prawo ochrony środowiska, że samo wyszukiwanie i przeglądanie informacji jest bezpłatne. Takie postawienie sprawy jest skorelowane z postępem cywilizacyjnym i technologicznym. Zwiększa się tym samym liczba nośników informacji oraz sposób dostępu do niej. Dlatego nie w każdym przypadku podmiot zainteresowany uzyskaniem konkretnej informacji musi osobiście zwracać się do organu administracji o udostępnienie informacji o stanie środowiska. W celu umożliwienia wykorzystania informacji o stanie środowiska $\mathrm{w}$ art. 30 ust. 1 ustawy określono, że informacje wymienione $\mathrm{w}$ tym przepisie są udostępniane za pośrednictwem publicznych sieci telekomunikacyjnych, a zwłaszcza przy wykorzystaniu elektronicznych baz danych. Warto zatem zwracać uwage na nowe rozwiązania teleinformatyczne, które będąc wynikiem rozwoju i postępu umożliwiają pozyskiwanie merytorycznych informacji w sposób obiektywnie prosty i tani, z zachowaniem standardów ochrony środowiska.

Wskazane możliwości uzyskania informacji dotyczących środowiska naturalnego oraz jego ochrony jest przeniesieniem zasad państwa demokratycznego do szerokiej gałęzi prawa, jaką jest ochrona środowiska. Społeczeństwo ma prawo do uzyskiwania informacji, które są istotne dla jego funkcjonowania, a z pewnością informacje dotyczące środowiska należy za takie uznać. Ustawa prawo ochrony środowiska wskazuje również na udział społeczeństwa w procedurach dotyczących realizacji praw i obowiązków z zakresu ochrony środowiska i zrównoważonego rozwoju. Uprawnienie dotyczy z jednej strony prawa $w$ indywidualnych sprawach administracyjnych, w których są wydawane decyzje administracyjne, $\mathrm{z}$ drugiej natomiast - $\mathrm{w}$ postępowaniach związanych $\mathrm{z}$ tworzeniem aktów generalnych związanych $\mathrm{z}$ ochroną środowiska.

8 Dz. U. z 2001r., Nr 112, poz. 1198 ze zm. 
Na podstawie przedstawionych argumentów słusznym wydaje się wniosek, iż prawno-administracyjne aspekty ochrony środowiska są w sposób immanentny związane z prawami obywateli, obowiązkami organów administracji publicznej, jak również praktyką i zwyczajami obowiązującymi w naszym kraju oraz w Unii Europejskiej. Zatem ich analizowanie ma z pewnością kontekst interdyscyplinarny, a istotny wymiar ochrony środowiska, będzie implikował skutek w postaci stosowania poprzez analogię porównań i przykładów nie tylko krajowych, ale międzynarodowych.

\title{
Legal and administrative aspects of environmental protection
}

\begin{abstract}
SUMMARY
Environmental protection is an area of interdisciplinary, in which the rule is the use of science concepts relevant to the legal, natural, technical or chemical. Therefore, in practice they may have different meanings depending on the conceptual context in which they are used. The concept, which draws attention to the rights and duties of citizens, public administration or environmental organizations, the legal and administrative aspects of environmental protection. Legal and administrative aspects of the environment in a manner related to the inherent rights of citizens, duties of public administrations, as well as practice and custom of our country and the European Union. Thus, their analysis is certainly an interdisciplinary context, and an important environmental dimension, the effect will be implied in the form of application by analogy comparisons and examples of not only national but international.
\end{abstract}

